\title{
Prevalence of carbapenemase production in Pseudomonas aeruginosa isolates causing clinical infections in Lagos University Teaching Hospital, Nigeria
}

\author{
${ }^{1}$ Ettu, A. O., *2Oladapo, B. A., and ${ }^{2}$ Oduyebo, O., O. \\ ${ }^{1}$ Department of Medical Microbiology and Parasitology, Lagos University Teaching Hospital, Nigeria \\ ${ }^{2}$ Department of Medical Microbiology and Parasitology, College of Medicine, University of Lagos, Nigeria \\ *Correspondence to: princesscathy1@yahoo.com; 08053505952
}

\begin{abstract}
:
Background: Pseudomonas aeruginosa has been highly associated with carbapenem resistance in which carbapenemases has been suggested to be a major contributory factor. Hence the objective of this study was to phenotypically detect KPC-type carbapenemase, metallo- $\beta$-lactamase and OXA-48 carbapenemase production in clinical isolates of $P$. aeruginosa in Lagos University Teaching Hospital (LUTH), Nigeria

Methodology: One hundred and seventy-one $P$. aeruginosa isolates consecutively recovered from clinical specimens of patients with infections at the Medical Microbiology and Parasitology laboratory of the hospital were identified using Microbact ${ }^{\mathrm{TM}}$ 24E kit. Preliminary screening for carbapenem resistance was determined by the disc diffusion method on Mueller-Hinton agar using single discs of meropenem and imipenem. Phenotypic detection of carbapenemase production among carbapenem-resistant isolates was performed by the combination disc test of meropenem-phenylboronic acid (MRPBO) and meropenem-dipicolinic acid (MRPDP) as recommended by EUCAST 2013 guideline.

Results: Out of the $171 \mathrm{P}$. aeruginosa isolates, $35(20.5 \%)$ were carbapenem non-susceptible (resistant) while carbapenemase production was detected in $27(77.1 \%)$ of these carbapenem resistant isolates, and no enzyme was detected in $8(22.9 \%)$. Of the 27 carbapenemase producing isolates, $22(81.5 \%)$ produced $\mathrm{MBL}, 1(3.7 \%)$ produced KPC, while $4(14.8 \%)$ produced both KPC and MBL enzymes.

Conclusion: This study revealed that carbapenem resistance among $P$. aeruginosa clinical isolates in our institution is gradually increasing. The mechanism for this rise is associated with carbapenemases, with MBL being the major carbapenemase involved. There is the need to ensure strict compliance with the LUTH infection control guidelines in order to check the rising incidence of infection caused by carbapenem resistant $P$. aeruginosa.
\end{abstract}

Keywords: carbapenemase; KPC; MBL; OXA-48; Pseudomonas aeruginosa; clinical isolates

Received Apr 8, 2021; Revised Jul 21, 2021; Accepted Jul 24, 2021

Copyright 2021 AJCEM Open Access. This article is licensed and distributed under the terms of the Creative Commons Attrition 4.0 International License $<$ rel="license" href="http://creativecommons.org/licenses/by/4.0/", which permits unrestricted use, distribution and reproduction in any medium, provided credit is given to the original author(s) and the source. Editor-in-Chief: Prof. S. S. Taiwo

\section{Prévalence de la production de carbapénémases dans les isolats de Pseudomonas aeruginosa causant des infections cliniques à I'hôpital universitaire de Lagos, Nigéria}

\author{
${ }^{1}$ Ettu, A. O., *2Oladapo, B. A., et ${ }^{2}$ Oduyebo, O., O. \\ ${ }^{1}$ Département de microbiologie médicale et de parasitologie, Hôpital universitaire de Lagos, Nigéria \\ ${ }^{2}$ Département de microbiologie médicale et de parasitologie, Faculté de médecine, Université de Lagos, Nigéria \\ *Correspondance à: princesscathy1@yahoo.com; 08053505952
}

\begin{abstract}
Abstrait:
Contexte: Pseudomonas aeruginosa a été fortement associé à la résistance aux carbapénèmes dans laquelle les carbapénèmases ont été suggérées comme étant un facteur contributif majeur. Par conséquent, l'objectif de cette étude était de détecter phénotypiquement la production de carbapénémase de type KPC, de métallo- $\beta$-lactamase et de carbapénémase OXA-48 dans des isolats cliniques de $P$. aeruginosa au Lagos University Teaching Hospital (LUTH), Nigeria.
\end{abstract}


Méthodologie: Cent soixante et onze isolats de $P$. aeruginosa récupérés consécutivement à partir d'échantillons cliniques de patients infectés au laboratoire de microbiologie médicale et de parasitologie de l'hôpital ont été identifiés à l'aide du kit MicrobactTM 24E. Le dépistage préliminaire de la résistance aux carbapénèmes a été déterminé par la méthode de diffusion sur disque sur gélose Mueller-Hinton en utilisant des disques uniques de méropénème et d'imipénème. La détection phénotypique de la production de carbapénèmes parmi les isolats résistants aux carbapénèmes a été réalisée par le test de disque combiné d'acide méropénème-phénylboronique (MRPBO) et d'acide méropénème-dipicolinique (MRPDP) tel que recommandé par la directive EUCAST 2013. Résultats: Sur les 171 isolats de $P$. aeruginosa, 35 (20,5\%) étaient des carbapénèmes non sensibles (résistants) tandis que la production de carbapénèmes a été détectée dans $27(77,1 \%)$ de ces isolats résistants aux carbapénèmes, et aucune enzyme n'a été détectée dans $8(22,9 \%)$. Sur les 27 isolats producteurs de carbapénémases, $22(81,5 \%)$ produisaient des MBL, $1(3,7 \%)$ produisaient des KPC, tandis que $4(14,8 \%)$ produisaient à la fois des enzymes KPC et MBL.

Conclusion: Cette étude a révélé que la résistance aux carbapénèmes parmi les isolats cliniques de $P$. aeruginosa dans notre institution augmente progressivement. Le mécanisme de cette augmentation est associé aux carbapénémases, la MBL étant la principale carbapénémase impliquée. Il est nécessaire de garantir le strict respect des directives de contrôle des infections LUTH afin de contrôler l'incidence croissante des infections causées par $P$. aeruginosa résistant aux carbapénèmes.

Mots-clés: carbapénémase; CPK; MBL; OXA-48; Pseudomonas aeruginosa; isolats cliniques

\section{Introduction:}

Pseudomonas aeruginosa is a member of the Gamma Proteobacteria class of bacteria, a Gram-negative aerobic bacillus belonging to the family Pseudomonadaceae (1). Pseudomonas aeruginosa is associated with varying degree of infections ranging from mild to severe infections. These include otitis externa, urinary tract infection, lower respiratory tract infections, folliculitis, keratitis, infection of corneal ulcers, endophthalmitis and opportunistic blood stream infection in immunocompromised patients. It is also an important cause of nosocomial infections such as ventilator-associated pneumonia and wound infections in burn patients, and causes damage to the lung tissue with decreased pulmonary function in patients with cystic fibrosis $(2,3)$. Pseudomonas aeruginosa is rarely a part of the microbial flora of healthy individuals, but may colonize the gastrointestinal tract of hospitalized patients, particularly neutropenic patients who have received previous antibiotic therapy (3). Pseudomonas aeruginosa is notoriously resistant to a number of antibiotics and only a handful of antibiotics are effective for treating infections caused by $P$. aeruginosa.

Carbapenems are class of beta-lactam antibiotics with a broad spectrum antibacterial activity. They are used in the treatment of severe infections caused by bacteria producing the extended-spectrum beta-lactamases (ESBLs) or multi-drug resistant Pseudomonas spp overexpressing chromosomal AmpC $\beta$-lactamases (4). Carbapenems approved for clinical use includes imipenem, meropenem, ertapenem and doripenem (5). The widespread occurrence of community-acquired bacterial isolates producing ESBLs capable of hydrolyzing almost all $\beta$-lactam antibiotics except the carbapenems (6), led to increased use of the carbapenems, which became very crucial for treating life-threatening infections that are often associated with modern medical techni- ques and practice such as transplantation, intensive care unit hospitalization and highly technical surgery (7). The subsequent emergence of carbapenem resistance has been largely associated with carbapenemase production. However, the actual prevalence of carbapenemase-producing bacterial strains remains unknown because many countries worldwide do not report rates of antibiotic susceptibility (8).

Carbapenemases are carbapenemhydrolyzing $\beta$-lactamases that are able to hydrolyze almost all $\beta$-lactams. Most are resilient against inhibition by commercially viable $\beta$-lactamase inhibitors (9). These enzymes are mostly of the Klebsiella pneumoniae carbapenemase (KPC), Verona integron-encoded metallo - $\beta$ - lactamase (VIM), imipenemase (IMP), New Delhi metallo - $\beta$ lactamase (NDM) and oxacillinase-48 (OXA48) types (10), which are enzymes in Ambler classes A, B, and D $(9,11,12)$. The Ambler class $A$ carbapenemases include the KPC $(9,13,14)$, Serratia marcescens enzyme family (SME), imipenem-hydrolyzing $\beta$-lactamase (IMI), "Not metalloenzyme carbapenemase" (NMC) $(9,11)$ and Guiana extended spectrum (GES) beta-lactamases (15). Although the KPC and GES $\beta$-lactamases are predominantly found in Enterobacteriaceae, there have been reports of these enzymes in $P$. aeruginosa (16-19). The Ambler class B metallo- $\beta$-lactamases (MBLs) include IMP, VIM-1, VIM-2, $(20,21)$, NDM-1, GIM (22), and Seoul imipenemase (SIM) (23). However, VIM and IMP have been reported in $P$. aeruginosa (20). The Ambler class $D$ serine-carbapene- mases include oxacillin-hydrolyzing (OXA) $\beta$-lactamases in which $P$. aeruginosa is one of the organisms where it has been mainly implicated $(11,24)$.

There are various strategies that have been proposed for detection of carbapenemases and the genes encoding them. A series of non-molecular tests have also been proposed for the detection of carbapenemase 
activity $(7,25)$ such as the inhibitor-based method which depends on demonstrating synergy between an indicator carbapenem and various in-vitro $\beta$-lactamase inhibitors. MBL inhibitors include ethylenediamine tetraacetic acid (EDTA) and dipicolinic acid (DPA), while inhibitors of KPC and other class $A$ carbapenemases are boronic acids, usually 3aminophenylboronic acid (APBA) or phenylboronic acid (PBA), although the mechanism of inhibition is not known (26-32). There is no known specific inhibitor for OXA-48-like carbapenemases but the disc diffusion assay using temocillin besides PBA and DPA, is usually utilized since OXA-48 confers high-level temocillin resistance. The objective of this study is to determine the prevalence of phenotypic KPC, MBL and OXA-48 carbapenemases production in clinical isolates of $P$. aeruginosa in Lagos University Teaching Hospital, Nigeria

\section{Materials and method:}

\section{Study setting}

The study setting is Lagos University Teaching Hospital (LUTH), a 764-bed tertiary care hospital in Lagos, southwest region of Nigeria, which service covers the entire Lagos State and neighboring Ogun State.

\section{Study design, protocol and ethical approval}

This is a laboratory-based study of $171 P$. aeruginosa isolates recovered by standard microbiological methods consecutively from clinical specimens of patients with infections, submitted to the Department of Medical Microbiology and Parasitology of the hospital between November 2014 and October 2015 (33). The isolates were identified to species level using the commercial Microbact ${ }^{\mathrm{TM}}$ 24E (Oxoid, UK) kit according to the manufacturer's instructions. The protocol for the study was approved by the Ethics Review committee of LUTH. Waiver of consent was approved and data were anonymized prior to analysis.

\section{Screening and phenotypic detection of carba- penemase production}

Screening for carbapenem resistance was determined by disc diffusion method on Mueller-Hinton agar using commercially available single discs of meropenem and imipenem (Oxoid, England, UK) (34). All isolates with zone diameter of inhibition less than the cut-off values for imipenem $(<23 \mathrm{~mm})$ and/or meropenem $(<25 \mathrm{~mm})$ (carbapenem resistant) were tested for phenotypic production of carbapenemases using the EUCAST 2013 guidelines (35). Phenotypic detection of carbapenemase production was performed by the combination disc test using commercially available tablets (Rosco Diagnostica Neo-Sensitabs, Rosco, Taastrup, Denmark) (36-37). The $\mathrm{KPC} / \mathrm{MBL}$ in $P$. aeruginosa Confirm Kit version
2 (98025) was used for testing according to the manufacturer's instructions.

The test was carried out on Mueller Hinton agar using the modified Kirby-Bauer method and EUCAST disk diffusion method 2013 version 3.0 (35). Few morphologically similar colonies of overnight pure culture isolates were inoculated into sterile normal saline and visible turbidity was adjusted to match the turbidity of 0.5 McFarland standards. The inoculum suspension was streaked onto Mueller-Hinton agar plate using a sterile swab stick. Tablets containing Meropenem

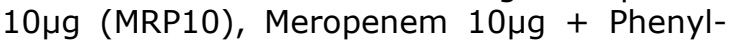
boronic acid (MRPBO) and Meropenem 10 $\mu \mathrm{g}+$ Dipicolinic acid (MRPDP) were applied and incubation was done at $35 \pm 1^{\circ} \mathrm{C}$ for $16-20$ hours. The zone diameter of inhibition of each isolate to the tablets was measured using a calibrated ruler, and result inter- preted using the EUCAST guideline.

When the zones of inhibition of MRP10, MRPBO and MRPDP were within $2 \mathrm{~mm}$ of each other, the isolate was reported as not producing $\mathrm{KPC}$ and MBL. When the MRPBO showed a zone difference of $\geq 4 \mathrm{~mm}$ from MRP10, the isolate was reported as demonstrating KPC activity. When MRPDP showed a zone difference of $\geq 5 \mathrm{~mm}$ from MRP10, the isolate was reported as demonstrating Metallo- $\beta$-lactamase activity. Only ceftazidime resistant isolates were tested, as false positive MBL may be obtained with ceftazidime sensitive isolates.

\section{Results:}

A total of $171 P$. aeruginosa were tested for carbapenem resistance and subsequently tested for carbapenemase production. The isolates were recovered from patients with sepsis $(n=3)$, ocular infections $(n=5)$, otolaryngeal infections $(n=22)$, chest infections $(n=7)$, intra-abdominal infections $(n=2)$, reproductive system infections $(n=3)$, bone/joint infections $(n=5)$, urinary tract infections $(n=$ $39)$, surgical site infections $(n=16)$ and wound infections $(n=69)$ (Table 1$)$.

A total of $35(20.5 \%)$ isolates were carbapenem non-susceptible (resistant) while carbapenemase production was detected in 27 $(77.1 \%)$, and no enzyme was detected in 8 $(22.9 \%)$ of the carbapenem resistant isolates. Of the 27 carbapenemase producing isolates, $22(81.5 \%)$ produced MBL, $1(3.7 \%)$ produced $\mathrm{KPC}$, and $4(14.8 \%)$ produced both $\mathrm{KPC}$ and MBL enzymes (Table 2).

\section{Discussion:}

In this study, the prevalence of carbapenem resistance among clinical isolates of $P$. aeruginosa in our institution was $20.5 \%$. This 
is similar to the findings in Turkey and India where the prevalence of carbapenem resistant $P$. aeruginosa was $20 \%$ (38) and $18.2 \%$ (39) respectively. This rate is quite high for a drug which is usually reserved for last resort use. Previous studies carried out in our institution reported prevalence rates of carbapenem resistance among Pseudomonas isolates to be $4.1 \%$ in 2007 (40) and 5.9\% in 2013 (33). Comparing the results of the two studies to this present one indicates that the prevalence of carbapenem resistance among $P$. aeruginosa isolates in our institution is increasing.

Carbapenemase production is the most predominant mechanism that confers clinically significant resistance to Gram-negative bacteria (GNB) (41-45), which is why most carbapenem-resistant $P$. aeruginosa isolates in our study (77.1\%) produced carbapenemases. This high rate of carbapenemase production was also reported by Ogbolu et al., (46) with a rate of $59.7 \%$ and by Mohammed et al., (47) with a rate of $82.1 \%$ in other institutions in Nigeria. Also, a study conducted in India (39) using two different types of phenotypic testing methods reported a high rate of carbapenemase production of $93.1 \%$ (combined disk synergy test) and $87.2 \%$ (double-disk synergy test). It should be noted that $22.9 \%$ of the carbapenem resistant $P$. aeruginosa isolates in this study did not produce carbapenemase, which suggests that other resistance mechanisms such as overproduction of AmpC cephalosporinase, drug efflux, and deficient production or loss of porins might be responsible for the carbapenem resistance in these isolates (48).

The most common carbapenemases produced by $P$. aeruginosa in this study were MBLs ( $81.5 \%)$ and KPC (3.7\%), which is similar to the findings of Mushi et al., (49) in Tanzania, whereas KPC was reported to be more common than MBL by Vanegas et al., (50) in Colombia.

Table 1: Distribution of Pseudomonas aeruginosa isolates from different infection sites in Lagos University Teaching Hospital, Nigeria

\begin{tabular}{ccc}
\hline Types of infection & $\begin{array}{c}\text { Frequency of } \boldsymbol{P} . \\
\text { aeruginosa }\end{array}$ & Percentage \\
\hline Sepsis/Bacteraemia & 3 & 1.8 \\
Eye infections & 5 & 2.9 \\
Otolaryngeal infections & 22 & 12.9 \\
Chest infections & 7 & 4.1 \\
Intra-abdominal infections & 2 & 1.2 \\
Reproductive system infections & 3 & 1.8 \\
Bone/Joint infections & 5.9 \\
Urinary tract infections & 39 & 22.8 \\
Surgical site infections & 16 & 9.4 \\
Wound infections & 69 & 40.4 \\
\hline Total & $\mathbf{1 7 1}$ & $\mathbf{1 0 0}$ \\
\hline
\end{tabular}

Table 2: Carbapenem resistant Pseudomonas aeruginosa and the carbapenemase types produced

\begin{tabular}{cc}
\hline Carbapenemase types & Frequency (\%) \\
\hline $\mathrm{MBL}$ & $22(62.9)$ \\
$\mathrm{KPC}$ & $1(2.9)$ \\
$\mathrm{KPC}$ and MBL & $4(11.4)$ \\
No enzyme & $8(22.9)$ \\
Total & $\mathbf{3 5 ( 1 0 0 )}$ \\
\hline $\mathrm{KPC}=$ Klebsiella pneumoniae carbapenemase; $\mathrm{MBL}=$ metallo- $\beta$-lactamase
\end{tabular}


The KPC/MBL confirmation kit used in this study could not detect OXA-48 enzyme. A more recent phenotypic detection method such as the carbapenem inactivation method (CIM) which detects KPC, MBL and OXA-48 enzymes, may have detected the OXA-48 enzymes if used in this study. However, this method was not available to us at the time of this study. Similarly, molecular methods which are reported to be more sensitive and specific in detecting KPC, MBL and OXA-48 genes, were not available for this study.

\section{Conclusion:}

In conclusion, our findings revealed that carbapenem resistance among $P$. aeruginosa clinical isolates in our institution, is gradually on the rise, with carbapenemases being the major contributory mechanism for this, which is line with previous studies in this institution. Also, it is noteworthy to emphasize that $P$. aeruginosa can produce more than one class of carbapenemases as reported in our study, which raises some concern. Our findings also have serious implication for antimicrobial therapy of $P$. aeruginosa infections and infection control measures in our environment, in view of the fact that new antibiotics are not forthcoming. Hence, the need to preserve the antibiotics we have now by embracing antimicrobial stewardship.

\section{References:}

1 Garrity, G. M., Winters, M., and Searles, D. B. Taxonomic Outline of The Procaryotes. In: Bergey's Manual Of Systematic Bacteriology. 2nd ed. New York: Bergey's Manual Trust/SpringerVerlag; 2001.

2 Winn Jr. W. C., Allen, S. D., Janda, W. M., et al. The Nonfermentative Gram-Negative Bacilli. In: Koneman's Color Atlas and Textbook of Diagnostic Microbiology. 6th ed. Philadelphia: Lippincott Williams and Wilkins; 2006: 316-55.

3 Henry, D. A., and Speert, D. P. Pseudomonas aeruginosa. In: Versalovic, J., Carrol, K. C., Funke, G., Jorgensen, J. H., Landry, M. L., and Warnock, D. W. (eds). Manual of Clinical Microbiology. 10th ed. Washington, DC: American Society for Microbiology Press; 2011: 677-691.

4 Antunes, N. T., Frase, H., Toth, M., and Vakulenko, S. B. The class A $\beta$-lactamase FTU-1 is native to Francisella tularensis. Antimicrob Agents Chemother. 2012; 56 (2): 666-671.

5 Bonfiglio, G., Russo, G., and Nicoletti, G. Recent developments in carbapenems. Expert Opin Investig Drugs. $2002 ; 11$ (4): 529-544

6 Pitout, J. D. D., and Laupland, K. B. Extendedspectrum beta-lactamase-producing Enterobacteriaceae: an emerging public health concern Lancet Infect Dis. 2008; 8 (3): 159-166.

7 Nordmann, P., Naas, T., and Poirel, L. Global spread of Carbapenemase-producing Enterobacteriaceae. Emerg Infect Dis. 2011; 17 (10): 1791-1798.

8 Nordmann, P., Dortet, L., and Poirel, L. Carbapenem resistance in Enterobacteriaceae: here is the storm! Trends Mol Med. 2012; 18 (5): 263-272.

9 Queenan, A. M., and Bush, K. Carbapenemases: the versatile beta-lactamases. Clin Microbiol Rev.
2007; 20 (3): 440-458.

10 Nordmann, P., Gniadkowski, M., Giske, C. G., Poirel, L., Woodford, N., and Miriagou, V. Identification and screening of carbapenemaseproducing Enterobacteriaceae. Clin Microbiol Infect. 2012; 18 (5): 432-438.

11 Bush, K., and Jacoby, G. A. Updated functional classification of beta-lactamases. Antimicrob Agents Chemother. 2010; 54 (3): 969-976.

12 Ambler, R. P. The Structure of $\beta$-Lactamases. Philos Trans R Soc B Biol Sci. 1980; 289 (1036): 321-331.

13 Yigit, H., Queenan, A. M., Rasheed, J. K., et al. Carbapenem-Resistant Strain of Klebsiella oxytoca Harboring Carbapenem-HydrolyzingLactamase KPC-2. Antimicrob Agents Chemother 2003 24; 47 (12): 3881-3889.

14 Alba, J., Ishii, Y., Thomson, K., Moland, E. S., and Yamaguchi, K. Kinetics study of KPC-3, a plasmid-encoded class A carbapenemhydrolyzing beta-lactamase. Antimicrob Agents Chemother. 2005; 49 (11): 4760-4762.

15 Poirel, L., Le Thomas, I., Naas, T., Karim, A..., and Nordmann, P. Biochemical Sequence Analyses of GES-1, a Novel Class A Extended-Spectrum beta -Lactamase, and the Class 1 Integron In52 from Klebsiella pneumoniae. Antimicrob Agents Chemother. 2000; 44 (3): 622-632.

16 Villegas, M. V., Lolans, K., Correa, A., Kattan, J. N., Lopez, J. A., and Quinn, J. P. First identification of Pseudomonas aeruginosa isolates producing a KPC-type carbapenemhydrolyzing beta-lactamase. Antimicrob Agents Chemother. 2007; 51 (4): 1553-1555.

17 Cuzon, G., Naas, T., Villegas, M., Correa, A., Quinn, J. P., and Nordmann, P. Wide dissemination of Pseudomonas aeruginosa producing beta-lactamase blaKPC-2 gene in Colombia. Antimicrob Agents Chemother. 2011; 55 (11): 5350-5353.

18 Poirel, L., Brinas, L., Fortineau, N., and Nordmann, P. Integron-encoded GES-type extended-spectrum beta-lactamase with increased activity toward aztreonam in Pseudomonas aeruginosa. Antimicrob Agents Chemother. 2005; 49 (8): 3593-3597.

19 Pfeifer, Y., Schlatterer, K., Engelmann, E., et al. Emergence of OXA-48-type carbapenemaseproducing Enterobacteriaceae in German hospitals. Antimicrob Agents Chemother. 2012; 56 (4): 2125-2128.

20 Kimura, S., Ishii, Y., and Yamaguchi, K. Evaluation of dipicolinic acid for detection of IMPor VIM- type metallo-beta-lactamase-producing Pseudomonas aeruginosa clinical isolates. Diagn Microbiol Infect Dis. 2005; 53 (3): 241-244.

21 Walsh, T. R., Toleman, M. A., Poirel, L., and Nordmann, P. Metallo-beta-lactamases: the quiet before the storm? Clin Microbiol Rev. 2005; 18 (2): 306-325

22 Farmer, J. J., Boatwright, K. D., and Janda, J. M. Enterobacteriaceae: Introduction and Identification. In: Murray PR, Baron EJ, Jorgensen JH, Pfaller MA, Landry ML, editors. Manual of Clinical Microbiology. 9th ed. Washington, DC: American Society for Microbiology Press; 2007: 649-669.

23 Noyal, M. J. C., Menezes, G. A., Harish, B. N., Sujatha, S., and Parija, S. C. Simple screening tests for detection of carbapenemases in clinical isolates of nonfermentative Gram-negative bacteria. Indian J Med Res. 2009; 129: 707-712.

24 Zarrilli, R., Giannouli, M., Tomasone, F., Triassi, M., and Tsakris, A. Carbapenem resistance in Acinetobacter baumannii: the molecular epidemic features of an emerging problem in health care facilities. J Infect Dev Ctries. 2009; 3 (5): 335541.

25 Clinical and Laboratory Standards Institute. Performance Standards for Antimicrobial Susceptibility Testing; Twenty-Third Informational Supplement. CLSI document M100-S23. Wayne, PA: Clinical and Laboratory Standards 
Institute; 2013.

26 Birgy, A., Bidet, P., Genel, N., et al. Phenotypic screening of carbapenemases and associated $\beta$ lactamases in carbapenem-resistant Enterobacteriaceae. J Clin Microbiol. 2012; 50 (4): 1295-1302.

27 Giske, C. G., Gezelius, L., Samuelsen, Ø. Warner, M., Sundsfjord, A., and Woodford, N. A sensitive and specific phenotypic assay for detection of metallo- $\beta$-lactamases and KPC in Klebsiella pneumoniae with the use of meropenem disks supplemented with aminophenylboronic acid, dipicolinic acid and cloxacillin. Clin Microbiol Infect. 2011; 17 (4): 552-556.

28 Miriagou, V., Cornaglia, G., Edelstein, M., et al. Acquired carbapenemases in Gram-negative bacterial pathogens: detection and surveillance issues. Clin Microbiol Infect. 2010; 16 (2): 112122.

29 Pasteran, F., Veliz, O., Faccone, D., et al. A simple test for the detection of KPC and metallo$\beta$-lactamase carbapenemase-producing Pseudomonas aeruginosa isolates with the use of meropenem disks supplemented with aminophenylboronic acid, dipicolinic acid and cloxacillin. Clin Microbiol Infect. 2011; 17 (9): 1438-1441.

30 Pournaras, S., Poulou, A., and Tsakris, A. Inhibitor-based methods for the detection of KPC carbapenemase-producing Enterobacteria- ceae in clinical practice by using boronic acid compounds. J Antimicrob Chemother. 2010; 65 (7): 1319-1321

31 Kimura, S., Ishii, Y., and Yamaguchi, K. Evaluation of dipicolinic acid for detection of IMPor VIM- type metallo-beta-lactamase-prod-ucing Pseudomonas aeruginosa clinical isolates. Diagn Microbiol Infect Dis. 2005; 53 (3): 241-244.

32 Yong, D., Lee, Y., Jeong, S. H., Lee, K., and Chong, Y. Evaluation of double-disk potentiation and disk potentiation tests using dipicolinic acid for detection of metallo- $\beta$-lactamase-producing pseudomonas spp. and Acinetobacter spp. J Clin Microbiol. 2012; 50 (10): 3227-3232.

33 Osundiya, O. O., Oladele, R. O., and Oduyebo, $\mathrm{O}$. O. Multiple Antibiotic Resistance (MAR) Indices of Pseudomonas and Klebsiella Species Isolates in Lagos University Teaching Hospital. Afr J Clin Exper Microbiol. 2013; 14 (3): 164-168.

34 Clinical and Laboratory Standards Institute. Performance Standards for Antimicrobial Susceptibility Testing; Twenty-Fifth Informational Supplement. CLSI document M100-S25. Wayne, PA; 2015.

35 European Committee on Antimicrobial Susceptibility Testing. EUCAST guidelines for detection of resistance mechanisms and specific resistances of clinical and/or epidemiological importance Version 1.0. 2013. http://www.eucast.org

36 Yong, D., Lee, Y., Jeong, S. H., Lee, K., and Chong, Y. Evaluation of double-disk potentiation and disk potentiation tests using dipicolinic acid for detection of metallo- $\beta$-lactamase-producing pseudomonas spp. and Acinetobacter spp. J Clin Microbiol 2012; 50 (10): 3227-3232.

37 Fournier, D., Garnier, P., Jeannot, K., Mille, A., Gomez, A. S., and Plésiat, P. A convenient method to screen for carbapenemase-producing Pseudomonas aeruginosa. J Clin Microbiol. 2013; 51 (11): 3846-2848.

38 Kalayci, Z., and Aktas, E. Carbapenemaseproducing Pseudomonas aeruginosa isolates from Turkey; first report of $P$. aeruginosa high-risk clones with VIM-5 and IMP-7 type Carbapenemases in a tertiary hospital. J Diagn Microbiol Infect Dis. 2021; 99 (1): 115174

39 Nishu V., Ashok K. P., Baijayantimala M., Bijayini B., and Kavita G. Detection of Carbapenemaseproducing Pseudomonas aerug- inosa by phenotypic and genotypic method in a tertiary care hospital of East India. J Lab Phys. 2019; 11 (4): 287-291

40 Aibinu, I., Nwanneka, T., and Odugbemi, T. Occurrence of ESBL and MBL in Clinical Isolates of Pseudomonas aeruginosa From Lagos, Nigeria. J Am Sci. 2007; 3 (4): 81-85.

41 Zarrilli, R., Giannouli, M., Tomasone, F., Triassi, M., and Tsakris, A. Carbapenem resistance in Acinetobacter baumannii: the molecular epidemic features of an emerging problem in health care facilities. J Infect Dev Ctries 2009; 3 (05): 335341.

42 Miriagou, V., Cornaglia, G., Edelstein, M., et al. Acquired carbapenemases in Gram-negative bacterial pathogens: detection and surveillance issues. Clin Microbiol Infect. 2010; 16 (2): 112122.

43 Dortet, L., Poirel, L., and Nordmann, P. Rapid Identification of Carbapenemase Types in Enterobacteriaceae and Pseudomonas spp. by Using a Biochemical Test. Antimicrob Agents Chemother. 2012; 56 (12): 6437-6440.

44 Nordmann, P., Dortet, L., and Poirel, L. Carbapenem resistance in Enterobacteriaceae: here is the storm! Trends Mol Med. 2012; 18 (5): 263-272.

45 Teo, J., Cai, Y., Lim, T. P., Tan, T., and Kwa, A. Carbapenem Resistance in Gram-Negative Bacteria: The Not-So-Little Problem in the Little Red Dot. Microorganisms. 2016; 4 (1): 13.

46 Ogbolu, D. O., and Webber, M. A. High-level and novel mechanisms of carbapenem resistance in Gram-negative bacteria from tertiary hospitals in Nigeria. Int J Antimicrob Agents. 2014; 43 (5): 412-417.

47 Mohammed, Y., Zailani, S. B., and Onipede, A. O. Characterization of KPC, NDM and VIM Type Carbapenem Resistance Enterobacteriaceae from North Eastern , Nigeria. J Biosci Med. 2015; 2: 100-107.

48 Rodríguez-Martínez, J. M., Poirel, L., and Nordmann, P. Molecular epidemiology and mechanisms of carbapenem resistance in Pseudomonas aeruginosa. Antimicrob Agents Chemother. 2009; 53 (11): 4783-4788.

49 Mushi, M. F., Mshana, S. E., Imirzalioglu, C., and Bwanga, F. Carbapenemase Genes among Multidrug Resistant Gram Negative Clinical Isolates from a Tertiary $\mathrm{H}$-ospital in Mwanza, Tanzania. Biomed Res Int. 2014: 303104.

50 Vanegas, J. M., Cienfuegos, A. V., Ocampo, A. M., et al. Similar frequencies of Pseudomonas aeruginosa isolates producing KPC and VIM carbapenemases in diverse genetic clones at tertiary-care hospitals in Medell, Colombia. J Clin Microbiol. 2014; 52 (11): 3978-3986. 